\title{
Mexican Existentialist Ethics and the Pragmatic Authenticity of Rodolfo Usigli's El gesticulador
}

El artículo artículo indaga la génesis del existencialismo literario mexicano en El gesticulador de Rodolfo Usigli, estrenado en 1938. Elucida varias pulsiones clave del existencialismo mexicano desde 1938 en adelante, y sitúa el existencialismo literario de Usigli dentro de estas mismas pulsiones. Al hacerlo, el ensayo articula la profunda inclinación ética del existencialismo mexicano, forjado en la órbita del discurso identitario. Argumenta que el drama moralmente equívoco de Usigli inesperadamente hace causa común con esa inclinación: conjugando el arte teatral, la filosofía mexicana y la política posrevolucionaria, El gesticulador avanza una autenticidad pragmática basada en el altruismo, el comunitarismo y los principios por encima de la Verdad.

Palabras clave: Rodolfo Usigli, El gesticulador, literatura existencialista mexicana, filosofía mexicana, discurso identitario mexicano, política posrevolucionaria mexicana

This article explores the genesis of Mexican literary existentialism in Usigli's 1938 play, El gesticulador. It elucidates various key drives of Mexican existentialism from Usigli's moment onward and situates Usigli's literary existentialism within those drives. In so doing, the essay articulates the deeply-rooted ethical bent of a Mexican existentialism forged in the orbit of identity discourse. It argues that Usigli's morally equivocal drama makes unexpected common cause with that bent: dynamically conjugating stagecraft, Mexican philosophy, and post-revolutionary politics, El gesticulador advances a pragmatic authenticity based on altruism, communitarianism, and principles over Truth.

Keywords: Rodolfo Usigli, El gesticulador, Mexican literary existentialism, Mexican philosophy, Mexican identity discourse, Post-Revolutionary Mexican politics

el hacer bien, y el engañar bien. Miguel de Unamuno, San Manuel Bueno, Mártir (193I) 
In 1947, Rodolfo Usigli's play, El gesticulador, a hard-hitting indictment of post-revolutionary Mexican morality and politics, finally reached the stage after a nine-year delay. Just three years later, the Mexican public came face to face with a second debut of the play almost as momentous as the physical one. Octavio Paz's now canonical study of Mexican identity, El laberinto de la soledad, delivered a watershed account of El gesticulador along the lines of the continental existentialism that Paz and Usigli encountered when they worked together in Mexico's Paris embassy from I945 to 1946. This simple fact gives rise to arresting paradoxes: Usigli harbored no great fondness for French existentialism; he wrote El gesticulador in Mexico in 1938, before the heyday of post-Christian existentialism; still, Usigli's play, unmoored from absolutes as it is, can rightfully be considered the first literary existentialism to arise in Mexico, and Paz's interpretation of the drama rightfully enduring.r Usigli's claim that his stagecraft gave birth to a genuinely Mexican theater heightens the stakes intensely (TC3 497). ${ }^{2}$

The present article takes its cue from the paradoxes and takes them into the Mexican context that they beg. It aims to elucidate various key drives of Mexican existentialist discourse from Usigli's actual scene of writing shortly onward and to situate Usigli's inaugural literary existentialism within those drives. In so doing, my essay sheds light on the deeply-rooted ethical bent of a Mexican existentialism forged in the arena of identity discourse, an ethical bent with which Usigli's morally slippery $E l$ gesticulador makes improbable common cause through a potent mix of dramatic artifice and Mexican philosophy and politics.

In addition to paradoxes, Paz's celebrated treatise introduces an array of issues that bear on the foregoing agenda. For one, Laberinto cracks open the ethical complexities of truth when seen through an existentialist lens, in general, and in El gesticulador, in particular. Existentialism scaffolds much of Laberinto, and the chapter that contemplates Usigli's play, "Máscaras mexicanas," displays its au courant existential pedigree in spades. The masks that according to Paz Mexicans erect to protect themselves from the hostile gaze, the alienation that incites masking, the "amor a la forma" that symptomatizes it, and the repression that it presupposes all reverberate with the scare word of existentialism: inauthenticity. Curiously enough, the only redeeming quality of masks in the chapter involves the existential possibilities of lies, of "simulación." Rather than condemning lies, Paz teases out their potential for authenticity. Lies, he argues, can entail an existential becoming, the positing and achieving of a desired self when the mask fuses with the face. 3 
On Paz's reading, El gesticulador (henceforth, $E G$ ) offers a superb casein-point of a redemptive existential becoming. Laberinto maintains that the protagonist, César Rubio, lives his lie of being the original revolutionary, General César Rubio, authentically:

Simulando, nos acercamos a nuestro modelo y a veces el gesticulador, como ha visto con hondura Usigli, se funde con sus gestos, los hace auténticos. La muerte del profesor Rubio lo convierte en lo que deseaba ser: el general Rubio, un revolucionario sincero y un hombre capaz de impulsar y purificar a la Revolución estancada. (Paz, Laberinto 176 )

Therefore, "por el camino de la mentira podemos llegar a la autenticidad" (176). In unreservedly endorsing Rubio's ability to, as Unamuno would say, "engañar bien" and "hacer bien" (San Manuel 33), Paz renders the lie of Usigli's character not just existential but also unqualifiedly positive, an exemplary existential development.

Here we bump against another problematic aspect of Paz's reading. Much as Usigli may have appreciated his friend's favorable reception of the beleaguered EG, Paz's categorical interpretation could easily raise the dramatist's hackles because the mechanisms of the play - indeed, the very bedrock of Usigli's conception of the theater - militate against singular interpretations. Polemical and undecidable, $E G$ refuses to take a totalizing position on Rubio's lies, his impostures. Every stance that $E G$ tenders, we will see, has a counter-stance that keeps it in question, bouncing. The slippage between "descaro" and "valor" in this statement encapsulates the polemic that $E G$ unfolds: Rubio's rival for the office of governor, Navarro, says, "No sé cómo has tenido el descaro ... , el valor de meterte en esta farsa" (I89; ellipses in the original). Definitively resolving the slippage between shameless and valiant lie, purveying an unequivocal or singular position on the issues at hand would contravene Usigli's signature teatro de ideas, which dynamizes the theater into an agora, a public forum intended to provoke debate (Swansey 50). In the footsteps of George Bernard Shaw, Henrik Ibsen, and Anton Chekov, Usigli mounts a theater of ideas "que busca el debate en escena y fuera de la escena" (Corona 55), because he believes that an idée fixe is a dead idea. Characters come and stay alive "por cuanto son capaces de hacer frente a, o defender, nuevas ideas con caracteres ideológicos o ideístas," who are always mobile (Corona 56). All told, Usigli creates an aporetic theater that any treatment of his works, including mine, does well to take into account.4

Now, even as Paz, in France, sent Laberinto to Mexico for publication, he was aware of the existentialist Grupo Hiperión that had burgeoned 
there during his absence, and he was nervous about its reception of his work (Santí 45-6). Paz had good reason for concern because at home Hiperión had moved center stage into precisely the territory of Mexican identity discourse that Laberinto aimed to occupy. Hiperión made its debut in a Mexico City conference in 1948, just one year after the first performance of $E G$. Its core members included Ricardo Guerra, Jorge Portilla, Joaquín Sánchez Macgrégor, Salvador Reyes Nevares, Emilio Uranga, Luis Villoro, and Leopoldo Zea. All, plus Paz himself, had studied with José Gaos, one of several Spanish intellectuals whom president Lázaro Cárdenas had invited to Mexico after the defeat of the Republican cause in the Spanish Civil War. Gaos's desire to develop a genuinely Mexican philosophy electrified the interest of his students in Mexican identity, and they mobilized around the subject. The Hiperions encountered in the commitment of existentialism to Dasein (being-in-the-world), selfdetermination, and freedom, among other things, rallying points for their investigations of Mexico. The Grupo Hiperión, Guillermo Hurtado notes, aspired to "filosofar de manera original y auténtica como existencialistas mexicanos," whose object of study was neither humans in the abstract nor Europeans but Mexicans (xii). Young mavericks, the Hiperions swerved from the German existentialism of Gaos to the activist, cutting-edge, French existentialism of Sartre as a forcefield for their work. They disseminated their existential analyses of mexicanidad in a barrage of lectures and articles published in distinguished periodicals and books, such as the consequential book series, "México y lo Mexicano" (1952-1955), that Zea founded.

When Paz returned to Mexico in 1953, he kept his distance from Hiperión. 5 He subsequently contended that Laberinto's social, psychological, and political investments in Mexicanness differentiated it from Hiperión's ontological endeavors (Laberinto 42I). Be that or not the case, the fundamental divide between Laberinto and Hiperión lies in the latter's efforts to disrupt the pathologizing of Mexicans that Paz and Samuel Ramos carried out. Laberinto inscribed itself in the tradition of Ramos's 1934 El perfil del hombre y la cultura en México, then the most prominent of a chain of works that, conceivably stimulated by the denunciatory Spanish Generation of ' 98 to which Unamuno belonged, aimed to expose Mexico's ills in order purportedly to remedy them. Paz's massive jeremiad on his compatriots' alienation relieved in fiesta ebullience merely, so to speak, adds another piece to the Mexican tradition of caustic exposés that Roger Bartra decries in La jaula de la melancolía (1987). Usigli participated in the current. His "Epílogo sobre la hipocresía del mexicano" (1938; TC3) echoes Ramos's bleak account of his compatriots' inferiority complex and surpasses it, ripping into Mexicans' 
hypocrisy, pridefulness, negativity, machismo, brutality, and more. By contrast, Hiperión advanced a "concepción positiva, incluso reivindicatoria, de lo mexicano" (Hurtado xx). In 1952, for example, Uranga writes: "Todas las lucubraciones hasta hoy vigentes vienen a quedar relegadas ... mientras que suben al primer plano otras meditaciones que permiten hablar de una atmósfera de esperanza y de porvenir" (Análisis 150). Encouraged by the economic boom and political stability under president Miguel Alemán (1946-1952), envisaging the decline of Europe and a post-WWII ascendancy of the Americas, the Hiperions challenge the entrenched negativity of Mexican identity discourse. ${ }^{6}$

As they do so, an equally hallowed, competing discourse confederated with mexicanidad resurges and spills over into Hiperión - that of an affirmative ethics based on intersubjectivity and altruism set in motion by the first professional Mexican philosopher, Antonio Caso (I883-1946). Having served as director of the Escuela Nacional Preparatoria, rector of the national university reopened in I9IO after the Reforma, chair of the Facultad de Filosofía y Letras of the UNAM, and consistently a prolific author and inspired teacher, Caso was well known to the Hiperions and to Usigli. An homage to the recently deceased Caso held at the UNAM's Facultad de Filosofía y Letras in 1947, the year preceding Hiperión's inaugural event, finds Uranga and Zea, conceivably in search of a Mexican beacon, paying tribute to the philosopher. Uranga urges his peers to cultivate a "verdadera dedicación" to Caso's thought ("Antonio Caso y Emilie" 220). Zea exhorts his generation, which strives to "hacer de la realidad mexicana un objeto digno de reflexiones filosóficas," to "considerar a Antonio Caso como maestro" ("Antonio Caso y la Mexicanidad" I08). For his part, Usigli had already met Caso by I929, when he addresses him in a letter as "mi querido maestro" (though he likely awards Caso the title more honorifically than in point of fact, because Usigli had studied at the National Conservatory).7 Usigli and Caso intersected when Usigli gave summer courses on drama at the Facultad de Filosofía y Letras, starting in 1931. Caso sponsored Usigli for diplomatic service (1930), supported the publication of his México en el teatro (1932), and recommended Usigli for the fellowship at Yale that the dramatist won and accepted in 1936-1937.

Writing to Caso from New Haven on January 2I, 1936, Usigli declared him the fountainhead of Mexican philosophy, the "único maestro de México en tales materias." Without Caso, rationalism would have "acabado en México con el espíritu" (Letters to Antonio Caso). Usigli's comments reference the sea change in Mexican philosophy that Caso and his cohort had effected by challenging positivism, the official doctrine of Porfirio 
Díaz's long dictatorship (I876-I9II). The pathbreaking Ateneo de la Juventud, co-founded in 1909 by Antonio Caso, Pedro Henríquez Ureña, Alfonso Reyes, and José Vasconcelos, mounted the attack, which Caso spearheaded with his lectures on positivist philosophy in 1909. To the antimetaphysical, anti-spiritual, anti-aesthetic cast of Porfirian-Comtean Positivism, the Ateneo opposed the profile that Luis Villoro neatly summarizes: "Frente a la ciencia, [the Ateneo] levanta la metafísica; sobre el valor de la técnica se coloca el de la acción, moral o estética; frente al Estado, la persona humana; al culto excesivo de la razón se opone el impulso de la emoción o de la voluntad" ("Génesis" 235). Samuel Ramos, a student of Antonio Caso, reports that the heterogeneous participants in the Ateneo, which came to boast around a hundred members, shared an inclination to moral questions (I34).

Caso defined and epitomized that inclination in his masterwork, $L a$ existencia como economía, como desinterés y como caridad (henceforth Existencia). ${ }^{8}$ Caso first published the treatise in 1916, but he returned to Existencia and republished it throughout his life. He augmented the text in I919 and updated it substantially in 1943, shortly before his death and the advent of Hiperión. Thus, whereas the first two editions pit Henri Bergson and Arthur Schopenhauer against Positivism, the 1943 version adds disquisitions on Edmund Husserl and Max Scheler, among others. The three principal lines of Existencia announced in its title nevertheless remained firmly standing over time. Simply put, they contrast: I. Economy, the biological imperative of survival and the utilitarian self-interest that are the cornerstones of Positivism; 2. Disinterest, the partial transcendence of "economy," through the surpluses of play and esthetics; 3. Caridad, best translated as "altruism," the noble transcendence of "economy" through selfless love for one's fellow human beings. Caso, it is clear, has radically revised Comte's three stages of the theological, metaphysical, and scientific, most vividly by replacing science with altruism as the final, desired step of a teleological trajectory. 9

Beyond comprising the main pulsions of Caso's whole philosophy (Krauze 42), the desiderata of Existencia warrant close attention because they open up an ethics of altruism that pervades Mexican existentialism. In Caso's system, altruism implicates everything from interpersonal to metaphysical relations. It begins in the Christian Golden Rule of "do unto others as you would have them do unto you," "el amor al prójimo, verdad primera y única ... sola virtud; cumplimiento de la ley y los profetas, como dijo Jesús" (Caso II4; I919, I943). Coterminous with agape, charity "consiste en salir fuera de uno mismo, darse a los demás, en ofrecerse, en brindarse y prodigarse sin miedo de sufrir agotamiento" (I7; 1916). Charity begets 
community, a "city of God" on earth (II7; 1943). As Rosa Krauze, a leading authority on Caso's philosophy, states: "Caso reconoció que la realización humana ... no sería posible sin la colectividad" (Caso 178 ). Lastly, altruism provides a springboard from the city of God on earth to the actual heavenly city insofar as performing charitable acts escalates into a means of achieving salvation (Caso III; 1919, 1943).

It stands to reason, then, that when Caso treats existentialism, he would favor Christian existentialists. Indeed, the r919 edition (by intense implication) and that of 1943 (explicitly) display a Kierkegaardian Caso, captivated by a "perfectamente esencial" interiorized Christianity, a "Cristianismo novísimo y eterno, único, triunfante; cristianismo de Juan, con sus dos enseñanzas predilectas: el amor al prójimo y la vida eterna" (II4; 1919, 1943). While Martin Heidegger commands Caso's respect for his emphasis on Dasein, the "yo conjugado con la realidad" ("La metafísica del tedio y de la angustia" I30; 1939), he also incurs Caso's censure for having abandoned divine transcendence ("San Agustín y Heidegger" 170; 1944; on Caso and Heidegger, also see Krauze 226-30). Altruism, by contrast, enfolds the human and divine levels. "Es la experiencia fundamental religiosa y moral" (Existencia I7; 1916), says Caso, and on its own "la plenitud de la existencia" (I02; 1919, 1943). In Caso, as well as in a kindred Christian existentialist of the time, the French Gabriel Marcel (I889-1973), such plenitude allows intersubjectivity to be decoupled from Christianity and, in Caso's words, love to constitute the "ley única ley del mundo moral" (Existencia 19; 1916). ${ }^{\circ}$ While for Marcel one need not be a Christian to subscribe to his intersubjective ethics (44-5), Caso regards charitable acts as necessary precondition of faith ("La fe es imposible sin la caridad" [I8; I9I6 et passim]).

Both the viable dissociation of the human from the divine and the necessary association of the two recommend a platform of charity to the Hiperions. A Mexican world still largely steeped in Catholicism, and the Christian existentialists among the Hiperions, would welcome a faithbased morality; a post-Christian zeitgeist, like that of rigorously Sartrean existentialists, still gains credence from transvaluation, the reterritorializing of theology into the secular realm. Likewise, Caso's Existencia synchronizes with the preeminent tenet of French existentialism, freedom. Contesting positivism entailed contesting determinism, and embracing altruism entailed embracing free will. Caso stresses that everything we undertake "tiene sentido por la libertad de la persona humana. Somos la libertad misma" ("Trascendencia y libertad" 172; 1944). No less do freedom and self-determination speak to Mexicans forging their own identity, the crux of the Hiperión project. Existencia may 
offer up sheer philosophy, untethered from the Mexican condition, but its rebellion against Porifirian positivism, together with other works by Caso such as his El problema de México y la ideología nacional (1924), insert Existencia in the circuit of Mexican identity discourse. Zea, in fact, christened Caso the "paladín" of the Mexicanidad that the upcoming generation promotes (I07).

The pressures of identity discourse push Mexican existentialism towards moral questions. This, plus the robust bundle of appeals that Caso's philosophy held for Hiperión, induces a remarkable alignment of Mexican existentialist philosophy and literature with ethics. The development qualifies as remarkable on local and international fronts. First, "Sartre" was something of a dirty word for many non-Hiperión Mexican intellectuals. While Usigli repeatedly disparaged the tendentiousness of Sartre's theater (e.g., Corona 25), numerous pundits considered the Parisian's existentialism immoral and obscene (Merrim, "Los Cristos" 192-93). However, construed or misconstrued in Mexico, the early Sartre himself fell quite short of the mark in terms of ethics. The brutal portrait of human relations Sartre frames in the section on "Concrete Relations with Others" in Being and Nothingness (1943), little alleviated by the vague subjectivism - basically, in choosing for myself, I choose for humankind - of Sartre's 1946 Existentialism is a Humanism (25), and not at all by his failure to supply by the Hiperions' time the treatise on ethics he promises in the last sentence of the 1943 tome, left his existentialism suspended in a moral vacuum. Uranga's manifesto-like essay of 1949, "Dos existencialismos," describes his Mexican colleagues as avidly waiting to hear how Sartre would fill the void (Análisis 175).

Meanwhile, the Hiperions rushed in where angels, or Sartre, feared to tread. They plunged into the Sartrean breach and devised an existentialist ethics for Mexico, appreciably geared to altruism and community. Carlos Alberto Sánchez's Contingency and Commitment: Mexican Existentialism and the Place of Philosophy (2016), to my knowledge the first study to pinpoint the communitarian thrust of the Hiperions, observes that Mexican thinkers turned to "existentialism as a conceptual matrix for the reinterpretation of their reality [and urgently attempted] to locate an existentialist morality somewhere in the existentialist literature" (20). ${ }^{\text {II }}$ Joaquín Sánchez Macgrégor did exactly that in his contribution to Hiperión’s premiere, “¿Hay una moral existencialista?” (1948). His lecture and article acknowledge the perception of immorality or, at best, an "incierto contenido moral" in Sartre's works (Sánchez Macgrégor 268), a perception that Sánchez Macgrégor attributes to Sartre's preoccupation with ontology rather than morality (275). Undaunted, Sánchez Macgrégor 
continues the efforts to edge Sartrean ontology into an ethics already begun, he says, in 1947 by Francis Jeanson and Simone de Beauvoir (270). The Hiperión spotlights Sartre's overarching ethic of freedom, according to which "la libertad es principio y valor absoluto, alfa y omega de la existencia" (278). Nonetheless, in the next sentence, Sánchez Macgrégor adds that human beings realize their freedom in the midst of concrete situations, "atendiendo siempre a la libertad del otro" (278; emphasis in original; also see Sánchez 20). Allegedly extracted from Sartre, the fullerbodied ethics that Sánchez MacGrégor puts forth inflects care for the other, which Beauvoir champions in The Ethics of Ambiguity (1947) and elsewhere.

Sánchez Macgrégor, albeit significantly in Mexico, limits his sights to French existentialism. On the other hand, a raft of Hiperions formulated a situated, ethical existentialism wedded to Mexico. A few salient examples, discussed much more briefly than they merit due to space constraints, follow.

The stirring moves within Christian existentialism and indigeneity of Luis Villoro earn him an inalienable place on the roster. Villoro's 1948 debut article with Hiperión, "La reflexión sobre el ser en Gabriel Marcel," probes Marcel's ontological arguments, which, for Villoro, endorse the bridges that unite "el ser en general a los entes, a las existencias concretas" (290). Only by establishing such bridges through love, charity, and disponibilité (availability to others), writes Villoro of Marcel, can one realize the plenitude of Being (290-94). The symbiosis between Villoro and the lesser-known Mexican philosopher Alberto Menéndez Samará (I9081954) informs the matter at hand. In his 1949 article, "Génesis y proyecto del existencialismo en México," Villoro outlines Menéndez Samará's Menester y precisión del ser (1946), dedicated to Antonio Caso. Villoro pronouncedly shares with Menester and with Menéndez Samará's Esquema de un ideario (195I), as well as with Marcel, advocacy for love, overcoming the self/other binary, and the collectivity.

The preceding constellation girds Villoro's Los grandes momentos del indigenismo (1950), a milestone study of approaches to Mexico's Indigenous peoples. For Villoro, Indigenous Mexican culture represents an exemplar of community, the country's heart, its authenticity (274). He traces the history not of the Indigenous peoples per se but of indigenismo, the expedient, inauthentic positions on the Indigenous peoples that Mexican intellectuals have taken over the ages. Translator of Marcel and devotee of Kierkegaard, Villoro builds to the chapter entitled "Lo indígena como principio oculto de mi yo que recupero en la pasión," where, in a Kierkegaardian construction, "passion" designates "love" and "action" (283- 
84). Villoro maintains that by achieving solidarity with Indigenous peoples through "passion," mestiz@s can authentically recoup "lo indígena" held within and mitigate a history fraught with misprisons.

Other intellectuals affiliated with Hiperión navigate a course between critique of and panegyric to Mexican social bonds. Jorge Portilla's posthumously published (by Villoro, among others) Fenomenología del relajo undertakes to set his country on a "camino auténtico ... hacia una comunidad" (I4). It does so circuitously, through the figure of the obstreperous Mexican relajiento, who makes a mockery of values, or "seriousness," in public, stoking an oppositional community. On Portilla's interpretation, as relajientos defy seriousness and court chaos, they throw into relief the need for authentic, generous values (see Sánchez, chapters $\mathrm{I}^{-}$ 2). The chaotic community that relajientos instigate recalls Paz's fiesta, an unhinged form of collectivity and a pernicious obverse of alienation. As this implies, Paz may have distanced himself from Hiperión, but Hiperión did not fail to engage with Laberinto. Salvador Reyes Nevares and María Elvira Bermúdez, for example, interlace Paz with Hiperión thinkers like Uranga and Zea. Reyes Nevares's El amor y la amistad en el mexicano (I95I) and Bermúdez's La vida familiar del mexicano (1955), a major early study of Mexican gender relations, premise their sociological exposés on alienation, defined à la Laberinto. The two authors, however, ultimately maneuver away from Paz's blockages and towards intersubjectivity. Reyes Nevares lauds Mexicans' signal capacity for egalitarian friendship, which overcomes the power plays of erotic love that Paz and Sartre outline. Spinning out from Reyes Nevares into what sounds like Beauvoirian territory, Bermúdez imparts a seductive glimpse of gender equality, also modeled on friendship. ${ }^{22}$

Beauvoir and Sartre, both novelists, knew well that, given its ability to focus individual lives-in-the-making and in-situation, literature could be a privileged venue for existentialism. Literary works composed in the orbit of Hiperión took up the gauntlet and breathed new life into the dimensions of Mexican philosophy and identity discourse we have been tracking. The landmark Pedro Páramo (1955) by Juan Rulfo - a student of Caso's and a friend of Portilla's - meets both criteria. As substantiated in my "The Existential Juan Rulfo," Pedro Páramo signifies on Laberinto. The novel dramatizes the solitude of Mexicans, alienated in life by Pedro Páramo's despotic regime and still alienated in death. Rulfo suffuses collective fiestas (one that brought about the death of Pedro's father, another upon the death of Pedro's wife, Susana San Juan) with tragedy. He then furnishes a counterweight to Laberinto through the slender, yet powerful, cameo of the Indigenous group from Apango. The traders from Apango penetrate the Comala marketplace as a collective group, and as a group they rupture 
the dismal mestizo stronghold with their insouciant camaraderie. From the traders, Susana's nurse Justina buys her mistress herbs, products of the earth that associate their vendors with an undying tellurism and with an ancestral past of magic. The magical herbs function as an ever-expanding conduit to the mestiza Susana, whose erotic, mystical trances with her deceased first lover Florencio erect a zone of resistance to Pedro (" ¿Pero cuál era el mundo de Susana San Juan? Ésa fue una de las cosas que Pedro Páramo nunca llegó a saber" [165]). Yoked to the Virgin of Guadalupe through the imagery of moon and stars that clusters around Susana, the novel's heroine emerges as a gestural portrait of Villoro's "Lo indígena como principio oculto de mi yo que recupero en la pasión."

Rosario Castellanos magnifies the ethical compass of Mexican existentialism. Trained as a philosopher, once married to Hiperión's leading Sartrean, Ricardo Guerra, Castellanos enacts a many-splendored program of freedom: freedom for women, philosophical freedom, and freedom to embrace a collective Other. Migrating from the inexorable master-slave complex of her Indigenist novels (Balún-Canán, 1957; Oficio de tinieblas, 1962), to the prisonhouse of Sartrean interpersonal relations in the novel Rito de iniciación (drafted in 1965-1966 and published in 1997), Castellanos pushes through to a liberation from both in her poetry and essays. Simone de Beauvoir supplies the vital shifter, a real or de facto link to Caso's altruism. ${ }^{33}$ "Simone de Beauvoir o la lucidez," one of four hefty essays on Beauvoir in Castellanos's Juicios sumarios (1966), voices the Mexican author's primary affinity for Beauvoir outside the feminism of The Second Sex (1949), namely, that Beauvoir surmounts Sartre's notorious "Hell is other people." Beauvoir, observes Castellanos, knows that "el infierno son los demás pero también la única vía de salvación" (634). Hence, for Beauvoir "el Absoluto era entonces la felicidad, lo que implicaba el amor, la compañía, el servicio a los demás" (632). Castellanos reifies her own and Beauvoir's convictions in poems such as the one she chose for the title of her 1972 collected lyric, Poesía no eres tú. There we meet the fervent verses, equally kindred to Antonio Caso's beliefs: "El otro. Con el otro/ la humanidad, el diálogo, la poesía, comienzan” (199).

Castellanos's deflection to Beauvoir helps fill the moral vacuum left by Sartre and combats the pathologizing of Mexicans that Laberinto exhibits. Returning now to Usigli's El gesticulador and interrogating its ethics, no such clean resolutions present themselves. Instead, EG stammers and equivocates. Take its tragic ending. If, as Paz leads us to believe, César Rubio's lies have morphed into actions so admirable, so salutary, why must he die and his dreams for Mexico immediately evanesce, coopted by Navarro? The play certainly keeps us bouncing. Nonetheless, the preponderance of evidence that Usigli assembled in and around $E G$ 
valorizes Rubio's anomalous moral code. Crediting the good faith of Rubio's anagnorisis as an Other, multiple statements in $E G$ shake the public out of a morality predicated on absolutes and sway it towards the protagonist's relativized one. The most compelling such statements in $E G$ might be:

[Rubio to Navarro]: No soy César Rubio ... Pero sé que puedo serlo, hacer lo que él quería. Sé que puedo hacer bien a mi país impidiendo que lo gobiernan los ladrones y los asesinos como tú ... Empecé mintiendo, pero me he vuelto verdadero, sin saber cómo, y ahora soy cierto. Ahora conozco mi destino: sé que debo completar el destino de César Rubio. (Usigli, EG I92)

[Rubio to Elena]: Es que ya no hay mentira: fue necesaria al principio, para que de ella saliera la verdad. Pero ya me he vuelto verdadero, cierto, ¿entiendes? Ahora siento como si fuera el otro ... , haré todo lo que él hubiera podido hacer, y más. (I97; ellipses in original)

The excessive, though always revealing, apologetics for $E G$ that Usigli compiles in his essays further support the "false" Rubio. "No puede decirse," writes Usigli, "que el falso César Rubio, redimido de su mentira, transfigurado por la fe en la vitalidad de la Revolución y que muere por ella, sea un valor negativo" (TC3 534). And, the most forthright: "Es cristalina ... la circunstancia de que mi pieza no censura a los César Rubio-ni al verdadero ni al falso--, sino a los Navarros" (TC3 550).

The preceding battery of quotes bespeaks a destabilizing of truth and a jettisoning of ready-made, or "bad faith," morality so imperative to Usigli that he promotes it in $E G$ at the risk of controverting his protocol of undecidability. Remaking morality and discarding absolutes also feed into Usigli's conceptualization of lo mexicano at large. Another slice of that conceptualization, aside from Mexican hypocrisy, includes the suite of essays that Usigli composed on the seventeenth-century dramatist Juan Ruiz de Alarcón. Usigli began the essays in 1939, and he revised and published them in 1967 as Juan Ruiz en el tiempo. The essays all address the perpetual question of whether to consider Alarcón, raised in Mexico and transplanted to Spain, as Mexican or Spanish. Usigli goes dialectical. In what for recent scholars is a textbook definition of colonial criollismo, he deems Alarcón bicultural, a cultural voyager born in the colonies but aspiring to the metropolis $(J R 2, \mathrm{II})$. Suspended between two nationalities, the in-between Alarcón heralds the present-day anguished Mexican $U R 2$, 3). When Alarcón fulfills his dream and settles in the metropolis, he yearns wholly to inhabit the forms of Golden Age drama. Nonetheless, Usigli 
discerns in the transculturated author a forward-looking impetus to break out of Spanish forms.

Such structures of feeling manifest themselves, among several ways, in a disruption of rigid, categorical, Spanish morality. Usigli pictures Alarcón spurning "los vicios y las virtudes teologales" $(J R 3)$ that the missionary religious dramas he attended as a youth in Mexico imperiously expounded. Superseding facile moralizing, Alarcón brings a "moral moderna" to the stage $(J R$ 3), an ambiguous, relativized "ética nueva" that "realiza totalmente en el teatro la humanización de la moral cristiana" UR 3; emphasis added). Whence Alarcón's magnificent La verdad sospechosa, which renders the lies of fabulator Don García almost irresistibly alluring and assigns the liar a quite restrained punishment. As Usigli comments on the play: "Justamente no es moralista, aunque sea axiomático ... Si fuera moralista castigaría realmente a don García por mentir, en vez de hacer de él un verdadero artista" (JR 8). Usigli also stated that he wanted to write an adaptation of La verdad sospechosa, to be called La verdadera mentira (TC3 294). Though he never accomplished his plan to the letter, $E G$ accomplishes it in spirit. Read alongside Usigli's essays on Alarcón, $E G$ proves to concretize the break-out structures of feeling latent in La verdad sospechosa, to Mexicanize them, and thereby to restore the Mexican side of Alarcón's transatlantic identity.

As Usigli weds Mexican identity to a destabilized morality, it comes fully into view that placing the dramatist's oeuvre over/against signature aspects of Mexican philosophy, existentialism, and identity discourse yields, not answers, but a web of complications. Chief among them: how can the aporetic Usigli, with his ex-centric, almost post-factual notion of truth, relate to the moralistic Caso and his mid-twentieth-century successors? What breed of existentialism and ethics does Usigli - a dramatist rather than a philosopher per se - generate for his country? Does $E G$ map a way forward for Mexico? And finally, given Usigli's grandiloquent assertion that his "Epílogo sobre la hipocresía del mexicano" and Ramos's Perfil "fueron los precursores de todo el movimiento que han hecho los jóvenes, psicólogos y filósofos, de investigación y búsqueda del mexicano" (Rodríguez 54-55; emphasis added), was the contrarian Usigli yet another pathologizer, or did he body forth an enabling ethos in stride with Hiperión and its orbit? My essay will now hold up the pragmatic relativizing of truth attendant upon the philosophical horizon of Mexico in 1938, the year of $E G^{\prime}$ s genesis, as a means of responding to the complications; it then delves into $E G$ 's political agenda, the situational mover and shaker of Usigli's expansive pragmatic authenticity. 
Advents like Gregory Pappas's edited collection Pragmatism in the Americas (20II) have corroborated the hemispheric reach of early North American pragmatism, which, on the face of it, would seem to be an unlikely magnet for Mexican philosophy. After all, philosophical pragmatism crested around the time of the Spanish-American War and, thanks to its valorizing of practical consequences as the sine qua non of truth, came to be equated in the popular imagination with a positivistic utilitarianism. Antonio Caso and Pedro Henríquez Ureña, nevertheless, seized on pragmatism and tooled it into a vehicle for the Ateneo's humanistic project, validating the international current. William James in particular suited their needs. Scientist as well as believer in Christianity and in the sway of human experience, James could mediate between worldviews. It ensues that, in Existencia, Caso characterizes pragmatism as "un punto de vista sintético que, respetando el dato experimental, acatándolo plenamente, pugna también por conservar, sin contradicción, los valores más altos de la cultura y de la humanidad, el sentido idealista de la existencia, la religión y la moral" (56-57; 1943). He bifurcates pragmatism into its merely "economic" Comtean manifestations and its redemptive "charitable" strains. ${ }^{14}$ Predictably, love and action - "Sólo es bueno el que hace el bien" (Caso I02; 1919, 1943) - surface as prime draws of pragmatism for Caso.

Henríquez Ureña's 1908 Ateneo lecture injects a third party and an aberrant ethics, both crucial to Usigli, into the mix. Entitled "Nietzsche y el pragmatismo," it accords with Caso's revisionary sense of pragmatism as, in Henríquez Ureña's words, "anti-intellectualism" (i.e., against Kantian abstraction), "humanism," and "pluralism" (Henríquez Ureña 6r). The talk then pivots, in sentences larded with emphases, to the "surprising coincidences" between James and Friedrich Nietzsche (63), neither of whom affected the other. James, Henríquez Ureña proclaims, transfigures truth: "La verdad, para el pragmatismo, no es un valor absoluto, una cantidad fija e invariable: una idea se hace verdadera; su verdad es un suceso, un proceso: su verificación" (67). Nietzsche had already introduced the tendency: "Lo que importa, ha dicho Nietzsche, no es que algo sea verdadero (en el sentido estático del intelectualismo), sino que se crea en que algo es verdadero" (69). An extreme anti-intellectualist, Nietzsche had waged flat-out war on conventional values (Henríquez Ureña 63). The conjunction of James and Nietzsche leads Henríquez Ureña to ask, equally deconstructively and pragmatically, if truth may not resound with ambiguity (Henríquez Ureña 70).

We can now consider the fact that towards the end of his life Usigli declared Nietzsche the philosopher who most attracted him (Rodríguez 
68). Usigli analyzed Nietzsche's The Birth of Tragedy, but beyond that did not elaborate much on the attraction.15 Ramón Layera and Guillermo Schmidhuber have, examining correlations between Usigli's historical plays and Nietzsche's theories of the historian, the artist, and truth. The paths the two scholars lay, augmented by Usigli's reference in the 1943 edition of $E G$ to "aquel candor que Nietzsche señalaba como característica del artista puro" (TC3 489), strongly suggest the dramatist's familiarity with Nietzsche's "Truth and Lie in an Extra-Moral Sense" (1873). A seminal encapsulation of the German thinker's later philosophy, the short essay would beckon to Usigli as a wellspring for $E G$, especially owing to its involvement with "simulation," "dissimulation," and the creative mind.

To wit: setting the stage for later existentialism, Nietzsche's article rehearses his focal contention that there is no inborn structure, morality, or truth to the world. What pass as truths are "illusions" (Nietzsche 250), palliative fictions manufactured to make life bearable and to enable civilization. The rational individual, Nietzsche professes, simulates truths because they fulfill an instrumental function. Arthur Danto explains that Nietzsche "advanced a pragmatic criterion of truth" in which truth basically means "the facilitation of life" (54); as numerous scholars have investigated, Nietzsche and James intersect in accepting the expedient nature of truth. ${ }^{16}$ The German philosopher then explores its ramifications. Within the confines of pragmatic illusions, Nietzsche argues, society tags as objectionable "lies" anything patently self-serving or damaging to others (248). Conversely, standing apart from the herd, artists - "liberated intellects," "intuitive individuals - "dissimulate." That is, they dis- or unsimulate. Harbingers of the life-affirming, value-flouting Übermensch, creative minds embrace the manufactured nature of so-called truths and creatively play with serious matters. By "smashing and scorning the old conceptual barriers," the free intellect imbued with passion confirms "the domination of art over life" and conveys "an exalted happiness" (Nietzsche 256). Hyper-conscious, intuitive individuals may suffer, at times more than rational beings, but they hide their suffering in a "mask with a dignified harmony of features" (257).

One can easily picture the allure of Nietzsche's essay for Usigli. Reading it as an artist with an eye to Rubio qua artist, Usigli (and Paz, too?) would gain sustenance from the dissimulator, capable of overleaping conventional ethics and possessed of a visionary, salutary, authentic zeal. Withal, the richest template available to Usigli in 1938 for his specific designs would have to be Miguel de Unamuno's then-recent novella, San Manuel Bueno, Mártir (1931). Enormously influential in Spain and Latin America, San Manuel presents a scintillating trifecta of literature, proto- 
existentialism, and ethical dilemmas. The novella, furthermore, bears the stamp of William James's humanistic pragmatism. Unamuno once pronounced James "el pensador moderno que más me atrae" (qtd. in Urrutia 95), and Jaime Nubiola identifies Unamuno as "the first to spread pragmatist ideas in the Spanish-speaking world" (26). ${ }^{17}$ James, the Christian believer, and Unamuno, the agonista who yearns to believe, share a vision of truth as resulting from action and passion rather than as propelling them. Hence, in tandem with James and Matthew 7.I6, Unamuno avows: "Todo es verdad, en cuanto alimenta generosos anhelos y pare obras fecundas; todo es mentira mientras ahogue los impulsos nobles y aborte monstruos estériles. Por sus frutos conoceréis a los hombres y a las cosas" (Vida 92). Unamuno's credo, a plainsong that reaches across time and space, harmonizes with Nietzsche and Caso as well.

And, of course, with Usigli. The links between San Manuel and EG are virtually unmistakable. Don Manuel, the eponymous priest of Unamuno's parable, martyrs himself in life by purveying to his congregation an efficacious, pragmatic lie - a belief in the existence of the Christian afterlife that he excruciatingly doubts. Like Rubio, who dedicates his imposture to building a better Mexico, Don Manuel perpetrates a fiction for the sake of his community's well-being: “Lo primero ... es que el pueblo esté contento, que estén todos contentos de vivir" (Unamuno, San Manuel Io7). Outcomes and ethics thus prevail over metaphysics, the praxis of Christian morality over absolute truth. It follows that in the name of the greater good and with words transposable to Usigli's protagonist, Don Manuel spurns the label of hypocrite: "¿Fingir?, ¡fingir, no! ¡eso no es fingir! Toma agua bendita, que dijo alguien, y acabarás creyendo" (I22). The two gesticulators skirt demagoguery by placing weight on results for the collectivity, not rhetoric. Don Manuel wears the disguise of an orthodox priest, Rubio of a former revolutionary; both lay claim to authenticity by living their roles to others' benefit and to perfection. In sum, despite having sundered truth from absolutes, the humanistic pragmatism that circulated in both authors' milieux bequeathed them a field for ethical actions and communitarian values.

Akin to Unamuno, drawn to Nietzsche's artist, Usigli Mexicanizes the two authors' commingled pragmatism and proto-existentialism, firmly binding them in $E G$ to the post-Revolution "situation" of 1938. Politics moves the needle of that situation and of $E G$ : "En México," Rubio asserts in the play, "todo es política," "la política es el clima, el aire" (Usigli, EG I27) "que lo concatena todo" (I82), the politician "el eje de la rueda" (I83). The protagonist's allegation bespeaks the era in which Usigli composed his first works, one that witnessed striking negotiations with the goals of the Mexican Revolution. The official regime of Plutarco Elías Calles (I924-I928), 
widely perceived as having abdicated them, slacked off land reform and encouraged foreign investment in Mexico. When the end of Calles's term arrived in 1928, he installed a series of puppet presidents who mainly hewed to his will. The period now dubbed the "Maximato," in which Calles continued to prevail behind the scenes as the "Jefe Máximo," encompassed the brief regimes of Emilio Portes Gil, Pascual Ortiz Rubio, and Abelardo Rodríguez. Moreover, in 1929 Calles founded and led the Partido Nacional Revolucionario (the PNR), an umbrella party uniting disparate factions that would become the indefatigable Partido Revolucionario Institucional (the PRI). When the pro-socialist, pro-labor Lázaro Cárdenas assumed the presidency from I934-I940, he at long last shut down the "Maximato," reformed the PNR, and instituted sweeping changes such as land reform and the nationalizing of industry that honored the objectives of the Mexican Revolution.

Usigli joined the political fray. From 1935 to 1936, he served as the press secretary of Lázaro Cárdenas ( $T C_{3}$ 599-600), a man he admired mightily (e.g., letter to Caso, January 2I, 1936). Transmitting Usigli's political convictions, the Tres comedias impoliticas (TCI), written between 1932 and 1935, cement his role as a politically-engaged dramatist. The plays' thinly veiled à clef dimensions oppugn Calles, whom the playwright regarded as a demagogue and a strongman $\left(T_{3} 462\right){ }^{18}$ El gesticulador, almost needless to say, also demands to be read through a political lens. The subtitle, Pieza para demagogos, elicits the reading, and the contempt for demagogue Navarro and his local party that the drama blazons requires it. Usigli has repeatedly articulated the gist of $E G$, which unites its two hearts, politics and lying. For instance and centrally: "En $E G$ está implícita y evidente la lucha entre la verdad de la Revolución original y la mentira en la que han ensombrecido aquellos que, sin pureza ni capacidad creadora, se han valido de ella para fines personalistas y malvados" (TC 3 532-33). Usigli begins $E G$ by stating that it takes place in a generalized "hoy," but further on the play supplies a precise date of twenty-four years after 19I4; i.e., 1938, during Cárdenas era (136). Against this backdrop, Usigli inaugurates a Mexican literary existentialism that, by virtue of imaginatively redeploying Calles's "Revolutionary Family" propaganda campaign, gathers into a plea for community, love, and pragmatic authenticity. ${ }^{19}$

The Revolutionary Family campaign accompanied the formation of the PNR and extended well beyond it. Calles, the first Mexican president to capitalize on modern mass media, undertook in live and radio speeches that the press abundantly broadcast (Buchenau xxiv) to rewrite the Mexican Revolution, in essence reviving, reinventing, and betraying the ungainly movement. The Jefe Máximo's propaganda campaign 
transmogrified the Mexican Revolution into a solid front, reincarnated in the PNR. Diametrically opposed to the real Revolution, so notoriously beset by disunity and fragmentation, the initiative wove the war into a single fabric, a harmonious, politically expedient Revolutionary Family. According to Calles's idealized Revolutionary Family, a Freudian family romance of sorts, the Revolutionary Father led his children - the Mexican peasants, Indigenous peoples, and working classes - in a common battle against dictatorship. A mythologized Revolutionary Mother, a "saint and sufferer, whose moral superiority and spiritual strength acted as glue for the ultimate stability of the family" (Zolov 5), assisted the mythologized paterfamilias. The imagined community of Calles's Revolutionary Family envisaged the PNR as the "family home' in which postrevolutionary 'squabbles' were resolved" by a stern, benevolent father (4). The PNR would be synonymous with the post-factual Revolution, the Revolutionary Family, Mexican identity.

The symbolic Revolutionary Family was literally set in stone. The Art Deco Monumento a la Revolución built in the r93os still towers over Mexico City's Plaza de la República, where it serves as a mausoleum for Mexican presidents:

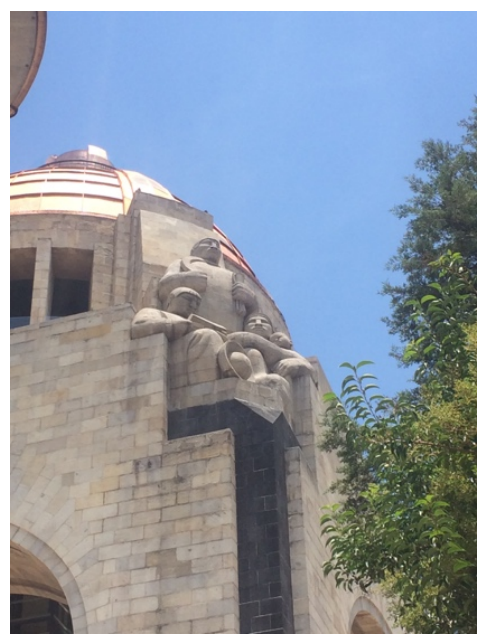

Figure ı. Monumento a la Revolución, detail. Photograph by Teresa J. Clifton

Originally, though, the sculpture commemorated the pillars of Mexican nationalism: Independence, the nineteenth-century Reform, and agrarian and labor laws (Olsen 79). Colossal trinities of a father, mother, and child comprise three of the four groups (in then-patriarchal Mexico, men alone 
would perforce symbolize the fourth, labor laws). Having lobbied strenuously for the edifice, Calles and Abelardo Rodríguez pressed it into service as a monument to the Revolutionary Family, alleged cardinal pillar of modern Mexico. An official ceremony that afforded "a suitable conclusion to Rodríguez's administration" (Olsen 80) inaugurated the stillunfinished monument on November 20, 1934. Usigli himself attended the ceremony, and he vented his ire at it in the conclusion to "Una comedia shaviana," written between 1933 and 1935 . Usigli accuses the monument of marking not the endless life of the revolution but its death $\left(T_{3} 376,378\right)$. He maligns the revolution-qua-family as a corrupt dynasty (TC 3377 ).

Usigli's outraged cognizance of Calles's propaganda machine, I believe, animates $E G^{\prime}$ s reenactments of the Revolutionary Family. For, aiming to divert the Revolutionary Family away from demagoguery into altruistic service of the collective good, $E G$ mimics and rewrites Calles's problematic script. Most obviously, both incarnations of César Rubio target the Revolutionary Father, fulcrum of Calles's campaign. The original Rubio, the general, "el hombre que explica la revolución mexicana, que tiene un concepto total de la revolución" ( $E G$ 137), compensates for what Usigli regards as the lack thereof in the Mexican Revolution ( $\left.T C_{3}{ }_{4}{ }_{43}\right)$. The second Rubio, the imposter, represents a constructive, healing amalgamation of "fathers." Usigli's gesticulator looks like Emiliano Zapata ( $E G$ II 8), shares Zapata's commitment to the pueblo, possesses Venustiano Carranza's strategic intelligence, has Pancho Villa's vitality, and operates from northern Mexico. In fact, the second Rubio takes Zapata's south to Villa's north, symbolically fusing the poles of the Revolution.

The larger footprint of the Revolutionary Family in $E G$ assumes the following contours. Rubio's family is dysfunctional, demoralized, riven. Whether reflecting the true state of the PNR, or, more likely, the nation as a conflictive family, the Rubio clan has reached a point of crisis. From the outset, family members tell the naked truth. Yet, the stark truth will not bring rebirth to the Rubios. Only the father can do so. And he can do so only by leaving the private sphere and entering the public sphere of politics for the common good. He must become the leader of the (Usigli's new) Revolutionary Family, not just of his own. In leaving the home, moreover, Rubio heals the nation-as family. Thus, the former professor's historical knowledge of the revolution, formerly dead currency, gains power when mobilized for the collectivity. Once the Harvard professor Oliver Bolton mistakenly exposes Rubio as the original general, Rubio the politician derives inspiration from the pueblo that spurs him to action, and he adopts it as his new, public family (Usigli, $E G \mathrm{I}_{162}, \mathrm{I76}, \mathrm{I} 83$ ). He unites the people, divergent leaders, and the party in common cause. Analogously, the Rubio reborn as a politician, "el latido, el corazón de las cosas" (I83), 
unites the private and public domains. He departs from the home and returns to it re-energized. As Rubio converts his home into a campaign headquarters, the public sphere invades and reinvigorates the private one.

The father's activism impacts his daughter, regenerating love. Rubio succeeds in awakening his daughter Julia to a better life, albeit one of rather bizarre proportions. At first he tries to coax the young woman into self-respect by peculiarly complimenting her "cuerpo admirable" (Usigli, $E G$ I26). Later, her father's consecration as a public figure galvanizes Julia into his most ardent champion. She attends his public rallies (204) and dreamily envisions her life with him when he is elected governor. Julia tells her mother, Elena: "Yo prepararé su ropa cada mañana, en tal forma que no pueda tocar su corbata ni sentir su traje sobre su cuerpo sin tocarme, sin sentirme a mí. Contigo consultará sus cosas, sus planes, sus decisiones, y cuando las realice te estará viendo y tocando" (205). Highly unnatural, the near-incestuous interactions between father and daughter are naturalized by the play's transactions with the Revolutionary Family. The taboo of incestuous love signals that Julia, like her father, must transcend the home. Hence Julia's successful seduction by the Revolutionary Father, leader of a collective initiative that gives her life a greater meaning (as well as material benefits, for the play keeps her motives bouncing). Julia, who sees herself as all ugly face, not beautiful body (126), will obtain a deeper beauty by uniting with the body politic: she falls in love with, wants to "marry," the father of the Revolutionary Family. So enamored is Julia with her father's communitarian efforts, so in thrall is she of a revitalized love for him, that she wishes to make the leap from revolutionary child to new revolutionary wife.

Julia's expression of that wish to Elena caps the play's scrutiny of the Revolutionary Mother. Party spokesperson Estrella initiates it in the second act by reciting the official version of the Revolutionary Mother to an Elena distressed by her husband's imposture and trying to extricate him from politics. "Pero usted, señora, debe recordar la gloriosa tradición de heroísmo y de sacrificio de la mujer mexicana," intones the Party leader. He cites the "símbolo de la femineidad mexicana, que es la soldadera" (Usigli, $E G$ I74), clearly seen as a camp-follower rather than a fighter. Elena wrestles with her conscience and convinces herself to accept César's lie because, and only because, it will benefit the family she loves (20I). Despite her moral misgivings always loyal, long-suffering, and heroically devoted to family, the traditional Elena embodies the Revolutionary Mother, as limned by Zolov above. Therein, for Usigli, lie her shortcomings. Elena is a realist with a limited vision, limited to the family. Intransigently, even selfishly, circumscribed to the private sphere, she cannot accept the husband who in serving the public will no longer require her to tend to his 
needs. When Rubio is elected governor, she says, "será como si me lo hubieran matado" (205). The logic of the play would then have it that Julia steps in as substitute "wife" of the father. She will be his helpmate for the public good in the outside sphere anathema to Elena. Youth and "fire" (II8), Julia will realize the progressive Usigli's ideal for a modern Mexican womanhood, a reimagined Revolutionary Mother.

$E G$ allows the Rubios' other child, Miguel, scant profitable commerce with the Revolutionary Family. A would-be revolutionary fervor converts Miguel into a fanatical defender of truth in its absolute form; to his detriment, he seems to share the infantilization bound up in Calles's notion of the Revolutionary Child, adrift and in need of the father's wise governance. Indeed, the puerile, cartoonish, Miguel complains and shouts and weeps his way through the play. He refuses to acknowledge the value of his father's public or private motivations. Is Miguel a farcical fool or a praiseworthy warrior? That is surely a key question, and the customary suspenseful Usigli ending declines to resolve it. At the last minute, Miguel absconds from the home, having finally mustered an existentially-tinged courage that might, just might, betoken the onset of maturity ("Se cubre un momento la cara con las manos y parece que va a abandonarse, pero se yergue" [Usigli, $\left.E G_{2 \mathrm{II}}\right]$ ).

Miguel has kept absolutes visible and in motion. He also has acted as a foil for his father, who emblematizes a pragmatic authenticity. César Rubio, in telling contrast to his son, has already joined the public arena - and become an existential hero. As an existential hero in the European mold, Rubio is free, daring, self-creating, acting in good faith, making choices, profoundly in-situation. As a Mexican existential hero, he has realized an ethics of altruism, communitarianism, love, and availability (disponibilite). On both counts, César Rubio has traded essence for existence, forsaking absolutes in favor of praxis. Usigli's protagonist relocates Unamuno's San Manuel's capacity to "do good" by "deceiving well" to a Mexican domain, where the existential hero must contend with the ubiquitous corruption and lies of a post-Revolution political context. Only by fighting fire with fire, lies with lies, can one implant authentic action in such a no-exit scenario.

$E G$ thereby emits a defense of pragmatic authenticity that coalesces into a spirited message: If you want to be a major player in a Mexico rife with hypocrisy, if you want to succeed in implementing the goals of the Mexican Revolution, you have to be willing to play the game with all the weapons of the political milieu (lies, demagoguery, blackmail, anything but violence), to get your hands dirty. You have to give up notions of truth with a capital $\mathrm{T}$, which cannot survive in the public arena or serve the public good, and uphold principles rather than Truth. Choose your truth 
according to noble standards, live it authentically. Play the game of Mexican politics but with ethics, daring, heart.

The twists that $E G$ visits on what we could call Bolton's gringo logic underscore Rubio's transformation into a worthy Mexican existentialist hero. Bolton's thinking prompts Rubio's initial imposture. In the first act, Rubio astutely surmises that Bolton abides by two dubious presumptions: an unshakeable faith in logic consistent with Caso's merely "economic" Positivism ("La verdad siempre es lógica" [Usigli, EG I42]) and an exoticizing view of Mexico as "maravilloso," a country where "la verdad es más extraña que la ficción" (156). The at first opportunistic protagonist combines the mutually exclusive propositions and sells Bolton the truth to which the North American professor subscribes, in the guise of a logical, marvelous original Rubio. The second and third acts of $E G$ then walk away from both flawed premises of gringo logic. They enter into a supple, pragmatic orbit that operates on a passionate, altruistic commitment.

Usigli's Rubio models these traits for his fellow citizens, offsetting ingrained adverse characterizations of Mexicans. And yet, Rubio suffers and dies. In an existential framework, his suffering has heightened standing. Rubio does not insouciantly glide into his new identity, which would invite accusations of bad faith and fraud. Instead, Act 2 shows the protagonist falling victim to his own crime. Tortured by guilt, Rubio cannot spend the blood money obtained from imposture. Usigli's protagonist emerges from the trauma purified. When he appears in Act 3, the stage directions read: "En estas cuantas semanas se ha operado en él una transfiguración impresionante. Las agitaciones, los excesos de control nervioso, la fiebre de la ambición, la lucha contra el miedo, han dado a su rostro una nobleza serena y a su mirada una limpidez, una seguridad casi increíble" (Usigli, EG I8I). Kierkegaardian anguish, the Unamunian agonista, the passion and suffering of the hyper-conscious Nietzschean dissimulator, and a transvalued Christianity all crowd together here to ratify Rubio as authentic, as an existential hero. However, ephemeral the value of his death in the post-Revolution, post-factual climate, Rubio has died for a cause. Such, we might conclude, are the anchors of an ethical, humanistic truth in a world divorced from absolutes.

Brown University 
NOTES

I Usigli discusses French existentialism solely in terms of its theater, which he excoriates as propagandistic and as the opposite of dialogical, that is, as a theater à these (Corona 25 ).

2 Key to Usigli references in article: $E G=E l$ gesticulador; Corona=Corona de luz (Usigli's Teatro completo omits the play's important prologues); JR=Juan Ruiz de Alarcón en el tiempo; TC=Usigli's Teatro completo, followed by volume number.

3 Paz writes: "A cada minuto hay que rehacer, recrear, modificar el personaje que fingimos, hasta que llega un momento en que realidad y apariencia, mentira y verdad, se confunden" ( 170 ). On a broad scale, despite Laberinto's quite Sartrean-sounding perspectives on bad faith, the gaze, and love, Paz much preferred Heidegger to Sartre, whom he considered derivative of the German philosopher. For a summary of Paz's critiques of Sartre, see his obituary for the philosopher, "Memento: Jean-Paul Sartre."

4 I borrow the term "aporetic theater" from Náter (24). Given Usigli's scorn of Sartre's theater, it is interesting that the Mexican author's mobile teatro de ideas and the ways his plays revolve around choice neatly parallel the French author's "theater of situations."

5 Santí authoritatively details Paz's involvement, or lack thereof, with Hiperión $\left(45^{-6}, 54\right)$. When Paz returned to Mexico in 1953 , he maintained relationships with some members of Hiperión, notably Emilio Uranga, but Paz himself did not participate in the activities of Hiperión. Paz acknowledged Hiperión only in the second edition of Laberinto (ch. 7), none too emphatically.

6 Uranga himself vindicates Mexicans on Ramos's characterological and on sweeping ontological grounds. His "Ensayo de una ontología del mexicano" (I951; in Análisis, I13-25), for instance, segues from Mexicans' alleged inferiority complex to their ontological state of insuficiencia. Despite its seeming negative valence, insuficiencia represents what Uranga pervasively terms accidentalidad and zozobra: the contingent, mobile, altogether human ontology that Mexicans embody, versus a fixed, essentialized, European substantiality. "No se trata de construir lo mexicano" as human, but "de construir lo humano como mexicano," writes Uranga in Análisis del ser del mexicano (1952; 45). Conversely, overlooking the humanistic values treated herein, Ana Santos Ruiz's vast indictment of Hiperión as complicit with the political regime reads Uranga \& Co. as still bent on pathologizing Mexicans in order to promote their compatriots' redemption through alemanismo's materialistic, bourgeois "doctrine of Mexicanidad." 
7 Warmest thanks to Carly Sentieri, Curator of Special Collections at Miami University for sending me Usigli's invaluable letters to Caso (dated I929, I930, and 1936) and related materials from the Rodolfo Usigli Archive.

8 I quote from the editions of Existencia that appear in Caso's Obras completas, vol. 3, which only includes the 1916 and 1943 editions, supplemented by a table detailing the contents of the I9I9 edition as well. I list the edition(s) in which the cited lines appear; page numbers reflect the first time that the lines appear in the two editions included in the Obras completas volume. The I9I6 edition runs from pp. $3^{-22}$ there. The articles by Caso that I cite, from 1939 and I944, are also included in Obras completas, vol. 3.

9 On continuities and discrepancies between Caso's and Comte's notions of altruism, see Stehn.

IO Completely independent of each other, often writing concurrently, Caso and Marcel develop strikingly similar arguments. As José Gaos commented in I952: "si hay un 'existencialismo cristiano,' representado por Marcel para el público internacional interesado en la Filosofía, representante no menos original y auténtico de él es Caso" (63). Krauze's book offers a detailed exposition of Marcel and Caso's commonalities on pp. $23^{-} 44$.

II With regard to values, see especially Sánchez's outstanding account of Hiperión's earliest contributions in his ch. I, the discussion of Portilla in ch. 2, and of Uranga in ch. 5. Sánchez's ch. 4, on Uranga and John Dewey, bolsters my later consideration of U.S./Hispanic pragmatism.

I2 Bermúdez's enlightened, pioneering work resonates uncannily with Beauvoir's The Second Sex (1949), particularly in terms of women's complicity with the patriarchy and the inspirational Mitsein (being-with, reciprocal relations of freedoms) threaded throughout Beauvoir's volume. Yet Bermúdez mentions neither Beauvoir nor Sartre, instead appearing only to extrapolate from Paz's Laberinto.

I3 Although it is unlikely that Castellanos studied directly with Caso, having, as far as I can tell, missed him by a couple of years at the UNAM, we know from the 1947 Homenaje that Caso was quite present to her generation. Furthermore, Caso's student, Oswaldo Robles, sat on the tribunal of Castellanos's M.A. thesis in 1950 (Schwartz 37).

I4 Eduardo García Máynez characterizes Caso’s pragmatism thus: “Es el pragmatismo humanista y cristiano de la existencia como caridad, no el pragmatismo miope de la existencia como economía" (56). On Caso's humanistic pragmatism, also see Ramos (137-42) and Krauze (53, 72-6, 92, 26970).

I5 Usigli discusses Nietzsche's The Birth of Tragedy, for one, in "Notas a Corona de fuego. A mixture of the Apollonian and the Dionysian, in Usigli's opinion, constitutes "el deleite de lo trágico" (TC 3793$)$. 
I6 On the thick matter of Nietzsche and James's pragmatic approaches to truth and for bibliography on the topic, see Fabbrichesi and Sinhababu. The two suggest that whereas Nietzsche jettisons pure truth, James retains belief in it yet considers it beyond our grasp, constantly subject to adjustment.

I7 Starting in I896 and for the rest of his life, Unamuno read and quoted James. His published works include thirty-two citations of James, over half of them from The Will to Believe (Nubiola 26). Unamuno's penchant for James has received much scholarly attention; see, for example, Farré's study.

I8 On the Tres comedias, see Layera, pp. $5^{\mathrm{I}^{-2}}$.

I9 To my knowledge, no one has associated $E G$ with the Revolutionary Family. Buchenau (ch. 6) is an excellent historical source on the Revolutionary Family per se, and Zolov, a richly suggestive one.

\section{WORKS CITED}

Be RM Ú DEZ, MARí A E L VIRA. La vida familiar del mexicano. Mexico City: Antigua

Librería Robredo, 1955.

BuChenau, J ÜRg. Plutarco Elías Calles and the Mexican Revolution. Lanham:

Rowman \& Littlefield, 2007.

Caso, a t o n Io. La existencia como economía, como desinterés, y como caridad.

Obras completas. Vol. 3. Ed. Rosa Krauze de Kolteniuk. Mexico City: UNAM, 1972.

Cast e llan os, ros a Ri o. Juicios sumarios and Poesía no eres tú. Obras II: Poesía,

teatro, y ensayos, Ed. Eduardo Mejía. Mexico City: FCE, 1998.

DAN T 0, ARThuR. Nietzsche as Philosopher. New York: Columbia UP, 2005.

FAB B RICHESI, Ro SE Lla. "Nietzsche and James. A Pragmatist Hermeneutics."

European Journal of Pragmatism and American Philosophy I (2009): I-I6.

FAR RÉ, L U IS. Unamuno, William James y Kierkegaard y otros ensayos. Buenos Aires:

Editorial La Aurora, 1967.

GAos, José. En torno a la filosofía mexicana. Mexico City: Porrúa y Obregón, 1952.

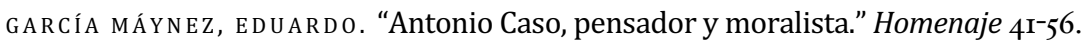
HENRí QUEZ UREÑA, PEDRo. "Nietzsche y el pragmatismo." Horas de estudio. Paris:

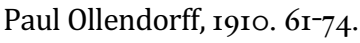

Homenaje a Antonio Caso. Mexico City: Editorial Stylo, 1947.

h U R TA D o, G U IL L e Rm o. "Introducción: El Hiperión y su tiempo." El Hiperión.

Antología, Ed. Guillermo Hurtado. Mexico City: UNAM, 2006. ix-xl.

krauze de Kolteniuk, rosa. "La filosofía de Antonio Caso. $4^{\text {th }}$ ed. Mexico City:

UNAM, I990.

LAYERA, RAM ÓN. "Mecanismos de fabulación y mitificación de la historia en las 'comedias impolíticas' y las Coronas de Rodolfo Usigli." Latin American Theatre Review I8 (1985): 49-55. 
mar Ce L, Ga B Rie L. The Philosophy of Existentialism. Trans. Manya Harari. New York: Citadel, I96I.

merrim, stephanie. "The Existential Juan Rulfo: Pedro Páramo, Mexicanness, and the Grupo Hiperión." MLN I29 (2014): 308-29.

—. "'Los Cristos de todas las pasiones': The Latin American Existentialism of José Revueltas's El luto humano." Revista Hispánica Moderna 69 (2016): 193-209.

NÁt e R, mi guel Á N Gel. Los demonios de la duda. Teatro existencialista hispanoamericano. San Juan: Editorial Isla Negra, 2004.

NiET ZSCHE, FRIEDRICH. "On Truth and Lying in an Extra-Moral Sense.” Friedrich Nietzsche on Rhetoric and Language. Ed., trans., and introduction by Sander Gilman, Carole Blair, and David Parent. New York: Oxford UP, I989. 246-57.

N U B I l a, JA I me. "The Reception of William James in Continental Europe." William James and the Transatlantic Conversation: Pragmatism, Pluralism, and Philosophy of Religion. Eds. Martin Halliwell and Joel Rasmussen. Oxford UP, 2014. I5-29.

olsen, patric e elizabeth. Artifacts of Revolution: Architecture, Society, and Politics in Mexico City. Lanham: Rowman \& Littlefield, 2008.

P A , o c T A vi o. El laberinto de la soledad. Ed. Enrico Mario Santí. Madrid: Cátedra, I993.

—. "Memento, Jean Paul Sartre." Hombres en su siglo. Mexico City, Seix Barral, I984. III-25.

PO RT I LlA, JO RGE. Fenomenología del relajo y otros ensayos. Mexico City: FCE, I984. RAmos, samuel. "Historia de la filosofía mexicana. Mexico City: Imprenta Universitaria, I943.

REYES NEVARES, SALVAD OR. El amor y la amistad en el mexicano. Mexico City: Porrúa y Obregón, 1952.

RODRíG UEZ, R OBERT o. "Vida y teatro de Rodolfo Usigli. 3 conversaciones." Tramoya I3 (1978): $47^{-5}$ O.

R u lf o, JuAn. Pedro Páramo. Ed. José Carlos González Boixo. Madrid: Cátedra, I999. SÁnCHEZ, CARlos A L Be RT o. Contingency and Commitment: Mexican Existentialism and the Place of Philosophy. Albany: SUNY Press, 2016.

SÁNCHEZ MACGRÉGOR, JOAQUÍN. “¿Hay una moral existencialista?” Filosofía y letras I5 (I948): $267^{-7} 78$.

SANTí, ENRICo maRio. Introducción. Paz, Laberinto. Madrid: Cátedra, I993. II-I32. S An t os Ruíz, an A. Los hijos de los dioses. El Grupo filosófico Hiperión y la filosofía de lo mexicano. Mexico City: Bonilla Artigas Editores, 2015.

SARTRE, JEAN-PAUL. Existentialism is a Humanism. Trans. Carol Macomber. Ed. John Kulka. New Haven: Yale UP, 2007.

SCHMidhuBer De la mora, Guillermo. Apología de Rodolfo Usigli: Las polaridades usiglianas. Guadalajara: Guadalajara UP, 2004. 
SChWA RTZ, PERLA. Rosario Castellanos: Mujer que supo latín. Mexico City: Editorial Katún, I984.

S I N H B A B U, N E I L. "Nietzschean Pragmatism." The Journal of Nietzsche Studies 48.I (2017): 56-70.

Stehn, alexander. "From Positivism to 'Anti-Positivism' in Mexico: Some Notable Continuities." Latin American Positivism: New Historical and Philosophical Essays. Eds. Gregory Gilson and Irving Levinson. Lanham: Lexington Books, 2OI4. 49-8I.

SWANSEy, B RUCE. Del fraude al milagro: Visión de la historia en Usigli. Mexico City: U Autónoma Metropolitana, 2009.

un a muno, migue L De. San Manuel Bueno, Mártir. Ed. Mario Valdés. Madrid: Cátedra, I984.

—. Vida de Don Quijote y Sancho. Madrid: Espasa-Calpe, I96I.

uRANGA, E milio. "Antonio Caso y Emile Meyerson." Homenaje 219-53.

-. Análisis del ser del mexicano y otros escritos sobre la filosofía de lo mexicano

(1949-1952). Ed. Guillermo Hurtado. Mexico City: Bonilla Artigas Editores, 2013. uR RUT IA, mANUE L MARía. Evolución del pensamiento político de Unamuno. Bilbao: Universidad de Deusto, 2009.

usigli, Ro do l fo. Corona de Luz: La Virgen. Mexico City: FCE, 1965.

-. El gesticulador. $2^{\text {nd }}$ ed. Ed. Daniel Meyran. Madrid: Cátedra, 2010.

-.Juan Ruiz de Alarcón en el tiempo. Web.

http://www.revistadelauniversidad.unam.mx/ojs_rum/index.php/rum/articl e/view/8925.

—. Letters to Antonio Caso. Rodolfo Usigli Archive, Miami U, Oxford, Ohio.

-. Teatro completo. Vol. I. Mexico City: FCE, I963.

—. Teatro completo. Vol. 3. Mexico City: FCE, I979.

villoro, Luis. "Génesis y proyecto del existencialismo en México." Filosofía y letras I8 (1949): 233-44.

-. Los grandes momentos del indigenismo en México. $3^{\text {rd }}$ ed. Mexico City: FCE, 1996. —. "La reflexión sobre el ser en Gabriel Marcel." Filosofía y letras I5 (1948): 27994. ZEA, LEO P L D O. “Antonio Caso y la Mexicanidad." Homenaje 95-Io8.

zoLOV, ERIC. Refried Elvis. The Rise of the Mexican Counterculture. Berkeley: U of California P, 1999. 